\title{
Evaluation of the Relationship Between Chronic Obstructive Pulmonary Diseases and Pulmonary Artery Diameter on Computed Tomography
}

\author{
Deniz Esin Tekcan Şanlı, ${ }^{1,2}$ (iD
}

${ }^{1}$ Department of Radiology, Acibadem Kozyatagi Hospital, Istanbul, Turkey

${ }^{2}$ Department of Medical Imaging Techniques, Vocational School of Heatlh Services, Istanbul Rumeli University, Istanbul, Turkey

Deniz Esin TEKCAN ŞANLI

Correspondence: Deniz Esin Tekcan Şanl। Department of Radiology, Acibadem Kozyatagi Hospital, Istanbul, Turkey

Phone: +905448104446

E-mail: tekcandenizesin@acibadem.com

\begin{abstract}
Purpose: To study that how the chronic obstructive pulmonary diseases (non-asthma-COPD) affect pulmonary artery diameters.

Methods: The main pulmonary artery diameter (MPAD), right and left main pulmonary artery diameter (RPAD-LPAD), and the ratio of MPAD to ascending aorta diameter (AAD) (MPAD/AAD) in all subjects of the sample were assessed. Cases with non-asthma-COPD were classified as Group 1; those who were not was categorized into Group 2. The link between non-asthma-COPD and diameters of pulmonary artery and also the ratio of MPAD/AAD was evaluated statistically according to the groups.

Results: In the study in which a total of 905 cases were evaluated, 138 in Group 1; 767 in Group 2. The patients' average age was $44.82 \pm 16.53$ (18-82). It was discovered that there is a statistically significant relationship between MPAD, RPAD and LPAD values and non-asthma-COPD, and it was higher in Group $1(p=0.049, p=0.011, p=0.022 ; p<0,05$, respectively). The MPAD/AAD value of the cases in Group 1 was discovered to be slightly higher than Group 2 ( $p=0.006$; $\mathrm{p}<0,01$ ). While the cut-off value for MPAD is $\geq 23.5 \mathrm{~mm}$, the odds ratio was 1.573 ( $95 \% \mathrm{Cl}: 1.092-2.267$ ); while the cut-off value for MPAD/AAD was $\geq 0.88$, the odds ratio was 1.918 ( $95 \%$ Cl: $1.253-2.938)$. According to ROC analysis, MPAD values were more specific for non-asthma-COPD than MPAD/AAD ratio, but MPAD/AAD ratio was more sensitive.
\end{abstract}

Conclusion: While there is a relationship between non-asthma-COPD and MPAD, RPAD, LPAD; the ratio of MPAD/AAD is more sensitive for the diagnosis of non-asthma-COPD.

Keywords: pulmonary hypertension, chronic obstructive pulmonary disease, emphysema, bronchiectasis, main pulmonary artery, chest CT

Kronik Obstrüktif Akciğer Hastalıkları ile Pulmoner Arter Çapı Arasındaki İlişkinin Bilgisayarı Tomografide Değerlendirilmesi

ÖZET

Amaç: Astım dışı kronik obstrüktif akciğer hastalıklarının (astım dış-KOAH) pulmoner arter çaplarını nasıl etkilediğini araştırmak.

Yöntemler: Çalışmaya dahil edilen tüm olguların ana pulmoner arter çapı (MPAD), sağ ve sol ana pulmoner arter çapı (RPAD-LPAD) ve MPAD'nin çıkan aort çapına oranı (AAD) (MPAD / AAD) değerlendirildi. Astım dışı KOAH'Iı vakalar Grup 1 olarak sınıflandıııldı; olmayanlar Grup 2 olarak adlandıııld. Astım dışı KOAH ile pulmoner arter çapları arasındaki bağlantı ve ayrıca MPAD / AAD oranı gruplara göre istatistiksel olarak değerlendirildi.

Bulgular: Toplam 905 olgunun değerlendirildiği çalışmada Grup 1'de 138; Grup 2'de 767 vardı. Hastaların yaş ortalaması $44,82 \pm 16,53$ (18-82) idi. MPAD, RPAD ve LPAD değerleri ile astım dışı KOAH değerleri arasında istatistiksel olarak anlamlı bir ilişki olduğu ve Grup 1'de daha yüksek olduğu tespit edildi ( $p=0,049, p=0,011, p=0,022 ; p<0,05$, sırasıyla). Grup 1 'deki vakaların MPAD/AAD değerinin Grup 2'den anlamlı olarak daha yüksek olduğu bulundu $(p=0,006 ; p<0,01)$. MPAD için limit değeri $\geq 23.5 \mathrm{~mm}$ iken, olasılık oranı 1.573'tü (\% 95 Cl: 1.092-2.267); MPAD/AAD için limit değeri $\geq 0.88$ iken, olasılık oranı 1.918 idi (\% 95 Cl: 1.253-2.938). ROC analizine göre, MPAD değerleri astım dışı KOAH için MPAD/AAD oranına göre daha spesifik, ancak MPAD / AAD oranı daha duyarlıydı.

Sonuç: Astım dışı KOAH ile MPAD, RPAD, LPAD arasında bir ilişki olmasına rağmen; MPAD/AAD oranı astım dışı KOAH tanısinda daha duyarlıdır.

Anahtar Kelimeler: pulmoner hipertansiyon, kronik obstrüktif akciğer hastalığı, amfizem, bronşektazi, ana pulmoner arter, toraks BT $\begin{array}{ll}\text { Received } & : 1 \text { May } 2021 \\ \text { Accepted } & : 8 \text { November } 2021\end{array}$ 
hronic obstructive pulmonary disease (COPD) is a chronic lung disease with rapidly increasing deaths worldwide (1). Although its main reason is smoking, some congenital and genetic conditions such as bronchiectasis may also lead to COPD. Although the diagnosis can be made basically by respiratory function tests, it can also be diagnosed by the computed tomography (CT) examinations, which are widely used nowadays, with its parenchymal findings $(1,2)$. It causes irreversible changes in lung histopathology that associated with clinical findings as a result of the inflammatory damage it causes in the chronic period. The most important of these is pulmonary hypertension ( $\mathrm{pHT}$ ) which emerges as a result of the resistance it creates in the pulmonary vascular bed. (1). In this study, pulmonary artery diameters were measured on CT examinations in patients with COPD and their relationship with possible parenchymal findings was evaluated. In this way, in cases with significant parenchymal findings in terms of COPD, pulmonary arterial structures will also be evaluated, clinicians and patients will be shed light on the treatment and the way to follow in terms of pHT, which is the most serious complication of the disease.

\section{MATERIALS AND METHODS}

The research was carried out with retrospective measurements on chest CTs taken in our hospital between 20192020. Patients with a diagnosis of non-asthma chronic small airway disease (COPD, emphysema, bronchiectasis) and patients with small airway disease findings (mosaic pattern, centrlobuler pattern, bronchiectasis) on chest CT were subjects of the study (Group 1). Patients with normal or almost normal lung parenchyma without obvious signs of infiltration in the lung parenchyma were selected as the control group (Group 2).
The control group consisted of those who had nodules smaller than $1 \mathrm{~cm}$ and no other parenchymal findings.

Patients with pleural effusion, consolidation, and infiltration were not included in the study. Patients who received radiotherapy to the chest region and patients with hypertension were also not included in the study. In addition, patients with known asthma, restrictive lung diseases and connective tissue disease were excluded from the study. The local institutional oversight board accepted this retrospective study (2021/07, 07.04.2021), and informed consent forms were obtained prior to CT acquisition.

Imaging Methods: All CT scans were done with Siemens Somatom Sensation-Syngo CT 2009 device. The acquisition parameters were standardized as; tube voltage: 140 $\mathrm{kV}$, tube current:40 mA, pitch:1,4, FOV:455 mm, slice thickness: $64 \times 0,6 \mathrm{~mm}$. The isolation rules were applied during and after the scanning had complied. All measurements were calculated by an experienced radiologist on chest CT.

Measurement Methods:The widest diameter perpendicular to the long axis of the main pulmonary artery diameter (MPAD) was measured with computer calipers at the level of the pulmonary artery (PA) bifurcation (Figure 1a). The diameters of the right and left pulmonar arteries (RPA-LPA) were measured at the widest portion, nearly 2 $\mathrm{cm}$ before the branching of the lobar arteries (Figure 1b1c) (3). The largest transverse diameter of the ascending diameter (AAD) was measured at the level of pulmonary bifurcation at the same level with MPAD measurement (3).
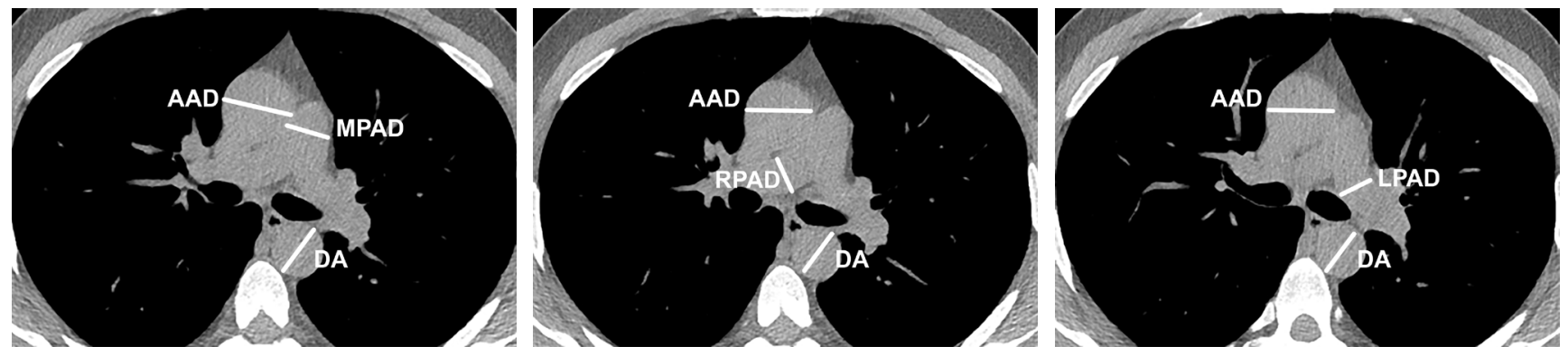

Figure 1: a) MPAD and AAD, b) RPAD, c) LPAD measurement location and method 
Statistical Analysis: Statistical analysis was performed using the NCSS (Number Cruncher Statistical System) software. The study data were evaluated using descriptive statistical methods (mean, standard deviation, median, frequency, percentage, minimum, maximum). The Shapiro-Wilk test and graphical analysis were used to determine if quantitative data are suitable for normal distribution. The Student-t test was used to compare normally distributed quantitative variables between two groups, while the Mann-Whitney $U$ test was used to compare non-normally distributed quantitative variables between two groups. The predictive value for the parameters was determined using diagnostic screening tests (sensitivity, precision, positive predictive value (PPV), negative predictive value (NPV), and ROC analysis. The threshold for statistical significance was set at p0.05.

\section{RESULTS}

The study involved a total of 905 cases, with $53.1 \%(n=481)$ being male and $46.9 \%(n=424)$ being female. The average age of the study participants was $44.82 \pm 16.53$ (18-82) years. $44.6 \%$ of the cases $(n=404)$ were under the age of 40 , while 55.4\% ( $n=501)$ were 40 and up. 15\% (n:138) of 905 patients had non-asthma COPD with imaging findings or according to the medical history (Group 1). 85\% (n:767) of cases had normal/close to normal CT findings and no history of COPD (Group 2).

A significant increase was found in MPAD, RPAD, and LPAD values according to the presence of COPD $(p=0.049$, $p=0.011, p=0.022 ; p<0.05$, respectively) (Table 1 ). In terms of MPAD/AAD ratios, a significant increase was found in patients with COPD $(p=0.006, p<0.05)$ (Table 1) (Figure 2). Mean MPAD/AAD ratio was $0.83 \pm 0.18$ in Group 1 ; and $0.79 \pm 0.15$ in Group 2.

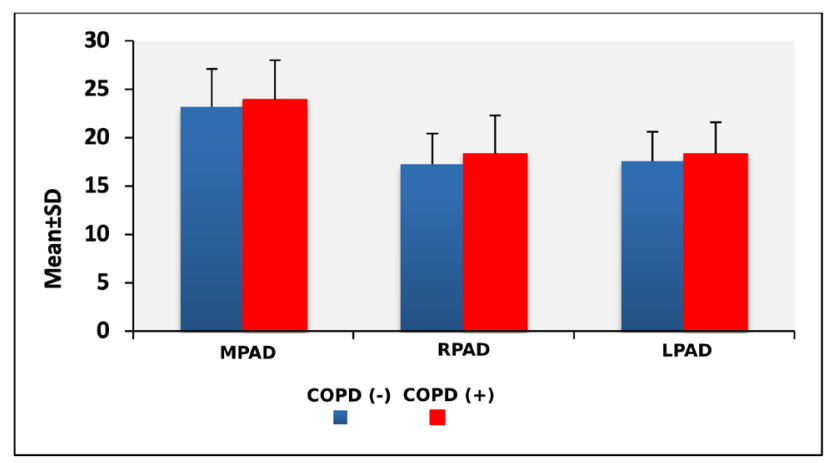

Figure 2: Graphical demonstration of pulmonary artery diameters according to the presence of COPD

According to the presence of COPD, the cut-off point for MPAD was found to be $23.5 \mathrm{~mm}$. For $23.5 \mathrm{~mm}$ cutoff value of MPAD; the sensitivity was $57.25 \%$, specificity $54.11 \%$, positive predictive value (PPV) $18.3 \%$, and negative predictive value (NPV) $87.6 \%$. The standard error was 2.6 percent, when the area under the ROC curve was 55.3 percent (Table 2).

A correlation was found between COPD and MPAD for $23.5 \mathrm{~mm}$ cut-off value $(p=0.015 ; p<0.05)$. When the MPAD value $\geq 23.5 \mathrm{~mm}$, COPD was 1.573 times higher in cases. The odds ratio for MPAD was 1.573 (95\% Cl: 1.092-2.267).

According to the presence of COPD, the cut-off value for $M P A D / A A D$ was $\geq 0.88$. For the 0.88 cut-off value of MPAD/ AAD; the sensitivity was $77.54 \%$, specificity $35.72 \%$, PPV $17.80 \%$, and NPV $89.80 \%$. The area under the ROC curve was $57.3 \%$ and the standard error was $2.6 \%$.

\begin{tabular}{|c|c|c|c|c|}
\hline & & non-astma COPD & Control & \\
\hline & & Group 1-(+) $(n=138)$ & Group 2-(-) (n=767) & $\mathbf{p}$ \\
\hline \multirow{2}{*}{ MPAD (mm) } & Min-Maks (Medyan) & $15-40(24)$ & $14-40(23)$ & \multirow{2}{*}{${ }^{a} 0.049 *$} \\
\hline & Mean \pm SD & $23.91 \pm 4.07$ & $23.19 \pm 3.91$ & \\
\hline \multirow{2}{*}{$\operatorname{RPAD}(\mathrm{mm})$} & Min-Maks (Medyan) & $12-30(17)$ & $10-30(17)$ & \multirow{2}{*}{${ }^{b} 0.011 *$} \\
\hline & Mean \pm SD & $18.33 \pm 3.94$ & $17.24 \pm 3.16$ & \\
\hline \multirow{2}{*}{ LPAD (mm) } & Min-Maks (Medyan) & $12-30(18)$ & $10-37(17)$ & \multirow{2}{*}{${ }^{b} 0.022 *$} \\
\hline & Mean \pm SD & $18.31 \pm 3.26$ & $17.58 \pm 3.01$ & \\
\hline \multirow{2}{*}{ MPAD/AAD } & Min-Maks (Medyan) & $0.43-2.42(0.81)$ & $0.49-1.36(0.78)$ & \multirow{2}{*}{${ }^{b} 0.006 *$} \\
\hline & Mean \pm SD & $0.83 \pm 0.18$ & $0.79 \pm 0.15$ & \\
\hline
\end{tabular}


Table 2. Diagnostic screening tests and ROC curve results for MPAD according to the presence of COPD

\begin{tabular}{|c|c|c|c|c|c|c|c|c|}
\hline & \multicolumn{5}{|c|}{ Diagnostic Scan } & \multicolumn{2}{|c|}{ ROC Curve } & \multirow[b]{2}{*}{$\mathbf{p}$} \\
\hline & Cut-off & Sensitivity & Specificity & $\begin{array}{c}\text { Positive } \\
\text { Predictive } \\
\text { Value }\end{array}$ & $\begin{array}{l}\text { Negative } \\
\text { Predictive } \\
\text { Value }\end{array}$ & Area & $\begin{array}{c}95 \% \\
\text { Confidence } \\
\text { Interval }\end{array}$ & \\
\hline MPAD & $\geq 23,5$ & 57,25 & 54,11 & 18,30 & 87,60 & 0,553 & $0,503-0,604$ & $0,045^{*}$ \\
\hline
\end{tabular}

A correlation was found between COPD and the MPAD/ AAD cut-off value of $0.88(p=0.002 ; p<0.01)$. In cases with MPAD/AAD is $\geq 0.88$, the probability of having COPD was found to be 1.918 times higher. The odds ratio for MPA/ AAD was 1.918 (95\% Cl: 1.253-2.938) (Figure 3).

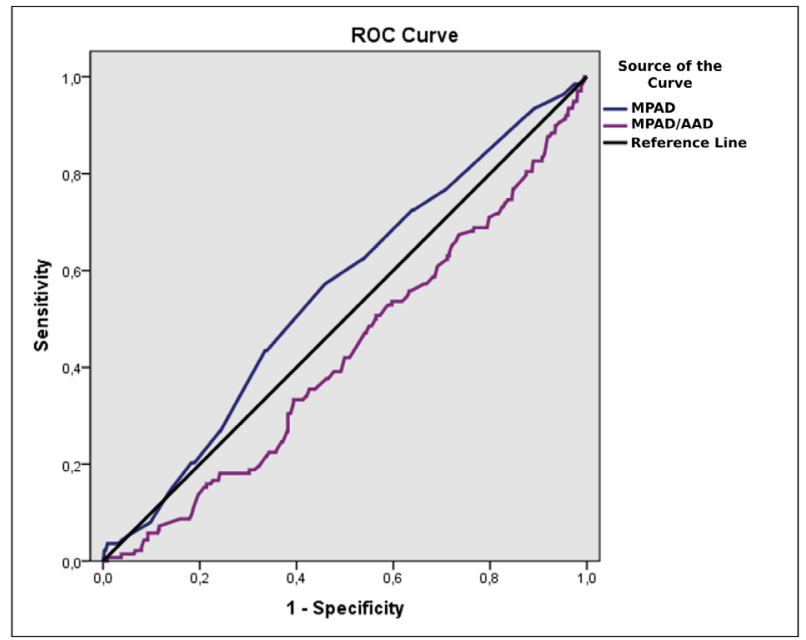

Figure 3: ROC Curve for MPAD only vs MPAD/AAD ratio by COPD presence

\section{DISCUSSION}

In our single-center retrospective study with a large patient population that evaluating the relationship between pulmonary artery diameters and MPAD/AAD ratios in patients with a diagnosis of COPD with parenchymal findings detectable by $C T$, as compared to the control group, all values (MPAD, LPAD, RPAD diameters, and MPAD/AAD ratio) were found to be significantly higher in COPD patients. Although MPAD/AAD is more sensitive in predicting COPD, MPAD values were obtained more specifically.

Pulmonary hypertension, which is an important complication in the course of COPD, is a leading cause of morbidity and mortality $(1,4)$. pHT is a common condition in patients with advanced stage COPD, it is usually moderate and progresses slowly (5). However, it is blamed for the dyspnea experienced by the patients by significantly affecting the quality of life (1). Impaired nitric oxide-prostaglandin balance in COPD as a result of chronic inflammation causes proliferation of pulmonary vascular intimal smooth muscle cells and accumulation of collagen and elastin fibers, thus playing a predisposing role for $\mathrm{pHT}$ $(1,6)$. Patients generally present with dyspnea, especially during exercise, as a result of inadequate expansion of vascular structures with impaired elasticity (6). This situation can be confused with dyspnoea caused by COPD. Therefore, in these patients, pulmonary artery pressures should be measured with echocardiography (1).

With the widespread use of $C T$, the diagnosis of parenchymal and vascular pulmonary diseases has become widespread (7). The diagnostic accuracy of CT in pulmonary diseases has been increased, as in all other areas, with improved image quality, new technological software programs and post-processing reformatted images (8). In our study, the relationship between parenchymal findings and pulmonary arterial vascular structures was mainly evaluated. As in our study, Chen et al. reported that MPAD, RPAD and LPAD in the COPD group had significantly higher values than the control group. (2). Similar values with our study were shown as MPAD $\geq 27.5 \mathrm{~mm}$, sensitivity $54 \%$, and specificity $80 \%$ (2). In the same study, while MPAD/ AAD cut-off value was $\geq 0.8586$, sensitivity was $58 \%$, and specificity was $69 \%$. In our study, while MPAD/AAD was $\geq 0.88$, sensitivity was higher with $77.54 \%$ and specificity was lower with $35.72 \%$. Similarly, Shin et al. showed that MPAD/AAD ratios for those with pulmonary hypertension and those without were 1.05 and 0.87 , respectively. $(p=0.0003)$ (8). The values in the group without $\mathrm{pHT}$ development were consistent with our study. The MPAD/AAD ratio was found to be an independent risk factor in the same reportin terms of pHT related mortality (9).

One of the major limitations of our retrospective study is that pulmonary artery pressure cannot be evaluated by echocardiography in patients included in the study. Although the overall number of patients who took part 
in the study is significantly higher than similar studies, the number of patients in the control group is much higher than the target group is another limitation of the study. Not to evaluate the clinical findings and the symptoms of the cases with imaging findings is a limitation, too.

This study showed that all pulmonary artery diameters and MPAD/AAD ratio were significantly higher in patients with COPD. It would be possible in this way to guide patients and clinicians in terms of early diagnosis of complications such as $\mathrm{pHT}$ before becoming symptomatic due to COPD with direct MPAD measurement or its ratio to AAD.

\section{DECLARATIONS}

Funding

The author received no financial support for the research, authorship, and/or publication of this article.

\section{Conflicts of Interest}

The author declares that there is no conflict of interest

\section{Ethics Approval}

The study protocol was approved by localethics committee (Date: 07.04.2021No: 2021/07).The study complied with the Declaration of Helsinki.

\section{Availability of Data and Material}

The materials described in the manuscript will be freely available to any scientist wishing to use them for noncommercial purposes, without breaching participant confidentiality.

\section{Authors' Contributions}

Concept - D.E.T.Ş.; Design - D.E.T.Ş.; Supervision - D.E.T.Ş.; Resource - D.E.T.Ş.; Materials - D.E.T.Ş.; Data Collection and/or Processing - D.E.T.Ş.; Analysis and/or Interpretation - D.E.T.Ş.; Literature Search - D.E.T.Ş.; Writing - D.E.T.Ş.; Critical Reviews - D.E.T.Ş.

\section{REFERENCES}

1. Wright JL, Levy RD and Churg A. Pulmonary hypertension in chronic obstructive pulmonary disease: current theories of pathogenesis and their implications for treatment. Thorax. 2005;60:605-9. DOI: 10.1136/thx.2005.042994.

2. Chen X, Liu K, Wang Z, et al. Computed tomography measurement of pulmonary artery for diagnosis of COPD and its comorbidity pulmonary hypertension. Int J Chron Obstruct Pulmon Dis. 2015;10:2525-33. DOI: 10.2147/COPD.S94211.

3. Truong QA, Massaro JM, Rogers IS, et al. Reference values for normal pulmonary artery dimensions by noncontrast cardiac computed tomography: the Framingham Heart Study. Circ Cardiovasc Imaging. 2012;5:147-54. DOI:10.1161/CIRCIMAGING.111.968610
4. Barberà JA and Blanco I. Pulmonary hypertension in patients with chronic obstructive pulmonary disease: advances in pathophysiology and management. Drugs. 2009;69(9):1153-71. DOI: 10.2165/00003495-200969090-00002.

5. Sakao S, Voelkel NF and Tatsumi K. The vascular bed in COPD: pulmonary hypertension and pulmonary vascular alterations. Eur Respir Rev. 2014;23:350-5. DOI: 10.1183/09059180.00007913.

6. Shujaat A, Bajwa AA and Cury JD. Pulmonary Hypertension Secondary to COPD. Pulm Med. 2012;2012:203952. DOI: 10.1155/2012/203952.

7. Lynch DA, Austin JH, Hogg JC, et al. CT-Definable Subtypes of Chronic Obstructive Pulmonary Disease: A Statement of the Fleischner Society. Radiology. 2015;277:192-205. DOI: 10.1148/ radiol.2015141579.

8. Matsuoka S, YamashiroT, Washko GR, et al. Quantitative CT assessment of chronic obstructive pulmonary disease. Radiographics. 2010;30:55-66. DOI: 10.1148/rg.301095110.

9. Shin S, King CS, Brown AW, et al. Pulmonary artery size as a predictor of pulmonary hypertension and outcomes in patients with chronic obstructive pulmonary disease. Respir Med. 2014;108:1626-32. DOI: 10.1016/j.rmed.2014.08.009. 